was the Kenya Group IV type Kw.D. (Type VIII of the American series).

Case 2.-An elderly male European with lobar pneumonia ; severe Type II infection. M.P.W. vaccine was given on the third day of illness. The temperature was $101.5^{\circ}$ the same

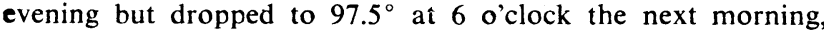
the patient feeling better and being less cyanosed; the temperature rose to $99.6^{\circ}$ the same evening. Vaccine was given again the following day, when the temperature was subnormal. Convalescence was regular from that date. The doctor in charge of the patient wrote, "One of the most successful cases of lobar pneumonia I ever had."

Case 3.-A female European with lobar pneumonia ; severe Type III infection. M.P.W. vaccine was given late in the iliness. The only notes available are the doctor's report that it was a good case and the patient made a quick recovery, the crisis occurring forty hours after the vaccine injection.

Case 4.-A female European with lobar pneumonia; extremely severe Type I infection. M.P.W. vaccine was given2,000 millions. The patient was said by the doctor in charge to be moribund when the first injection of vaccine was made, and he regarded this as the last hope. The next morning her condition was reported satisfactory. A second injection was given forty-eight hours after the first, and the crisis occurred within the next twenty-four hours. The doctor said that the vaccine "worked a miracle for the patient."

Case 5.-A male African with lobar pneumonia; severe infecting pneumococcus type "Kw.S." The mouse peritoneal exudate from which the vaccine was made included also a strain of Friedländer's bacillus, in numbers exceeded by the pneumococci, so that the vaccine necessarily contained both types of organism. M.P.W. vaccine was given; there was no toxic reaction. Crisis occurred the following day and convalescence was easy. This native case is included here because it was the only one in which a mixed vaccine was used, and it is typical of the few satisfactory native cases that were collected.

Case 6.-An elderly male European who had lobar pneumonia, Type $I$ infection, which proved fatal. He was given $0.08 \mathrm{mg}$. of M.P.W. vaccine. The only report received on this case was that the vaccine had " no effects."

Case 7.-An elderly male European suffering from a second attack of pneumonia, Type I infection, which ended fatally. M.P.W. vaccine was injected on the fourth day of the illness, the doctor first seeing him on the third day. His temperature dropped to normal about thirty-six hours after injection and the pulse to 106, and he appeared much less toxic. The temperature rose again, however, after a few hours, and he died four days later. Only one dose of the vaccine was given; if it had been repeated the illness might perhaps have run a different course. The vaccine was reported to have had no apparent effect in increasing the toxaemia, but to have been followed by a temporary improvement in the patient's general condition.

Case 8.-A European woman with very severe lobar pneumonia, Type I infection, ending in death. M.P.W. vaccine, 3,000 millions, was given. The temperature fell to $99^{\circ}$ the day following injection, but rose again, and the patient died about eighty-four hours later. Only one dose of the vaccine was given by the doctor, but it seemed that this effected a temporary improvement, and should have been repeated.

Case 9.-A male European aged 46, with lobar pneumonia which was extremely severe and involved both lungs. The infecting pneumococcus was a type of Group IV, unclassified. M.P.W. vaccine, 1,000 millions, was first injected about fortyeight hours after onset. During the next two days the patient appeared to be moribund; the Arneth count showed a marked shift to the left, the second lung became involved, and the doctor in charge was nervous of giving another injection of the vaccine. He was encouraged, however, to try a second dose of 1,000 millions seventy-two hours after the first. The next day there was general improvement in the patient's condition, speedily followed by the crisis, and he made a good recovery.

\section{Scheme of Dosage}

It is recommended that the injection be repeated on the following day if the first dose of vaccine has not lowered the temperature by that time; in cases where a good effect had resulted within about thirty hours after the first injection the vaccine might be repeated after forty-eight hours, and subsequently, if thought advisable, at intervals increasing from forty-eight hours to seventy-two, ninetysix, and one hundred and twenty hours. The vaccine should be repeated even when the patient's condition is worse on the day following the first dose: there need be no fear of increasing the toxaemia. It is noteworthy that in the handbook of the South African Institute for Medical Research the dose of 8,000 millions of Lister's prophylactic group pneumococcal vaccine is advised for treatment of pneumonia; and experiments in treatment with the same dose of a similar prophylactic vaccine issued in 1934 showed that the 8,000 millions were well tolerated by pneumonia patients.

\section{Summary}

An account is given of the types of pneumococcus found in lobar pneumonia cases in Kenya.

A case is stated for vaccine treatment of pneumonia.

A method for the rapid production of autogenous pneumococcus vaccine ("M.P.W.") is presented.

Details of nine cases of pneumonia treated with M.P.W. vaccine are appended.

\section{REFERENCES}

Fleming, A. (1938). British Medical Journal, 2, 37. Garnham, P. C. C., and de Smidt, F. P. G. (1931). Kenya E. Afr.

Wynn, W. H. (1934). British Medical Journal, 2, 1159.

\section{2-SULPHANILYL-AMINOPYRIDINE (M \& B 693) IN TREATMENT OF GONORRHOEA}

BY

\section{R. C. L. BATCHELOR, M.A., M.B., D.P.H., F.R.C.S.Ed. \\ ROBERT LEES, M.D., F.R.C.P.Ed. MARJORIE MURRELL, M.B., F.R.C.S.Ed.}

(From the Edinburgh Corporation and Royal Infirmary Venereal Diseases Department)

AND

\section{G. I. H. BRAINE, M.B., D.T.M.\&H. Colonial Medical Service}

Of the 102 cases of gonococcal infection included in this preliminary report, seventy-nine were in men, nineteen in women, and four in young girls. No adjuvant treatmentfor example, irrigations - that might be of material assistance was given during the use of the drug under consideration-M \& B 693. The results indicate a high proportion of apparent cures (over 91 per cent.).

Toxic effects were encountered in 29 per cent., and their nature and incidence are given later in tabular form. The commonest manifestations of intolerance were nausea and headache, and in most cases these symptoms were slight and the patients were able to continue with the drug in reduced dosage. The discontinuance of the drug was quickly followed by the subsidence of all the undesirable symptoms, and no prolonged ill effects were observed. 
In the successful male cases clinical cure was attained in under a week. In the successful female cases signs which might be interpreted as denoting infection persisted for two weeks, but gonococci disappeared from the smears almost as quickly as in the male cases (under three days). Thus in the early cases the gonococcal infection was cured before the time when the disabling complications-for example, epididymitis or salpingitis-are to be expected. Also, cure was effected without the time-consuming and often badly applied local irrigation treatment which was such a prominent feature of the old therapeutic regime. In the future the nightmare of stricture of the urethra, with its ever-present threat of retention or extravasation of urine, should cease to disturb the slumbers of those males whose weakness is sexual indiscretion, and the depressing picture of the chronic pelvic invalid should be less often encountered among the habitués of spas and health resorts.

Above all, the possibility of spread of the disease should be greatly reduced through the shortening of the period of infectivity. There is therefore every likelihood of a progressive diminution in the incidence of gonorrhoea, and designers of venereal disease clinics will plan on less spacious lines, especially in the accommodation required for irrigation treatment.

\section{Standard of Cure}

The standard of cure aimed at, but at the time of assessment not achieved in all the cases quoted, was as follows:

All cases are observed for a minimum of three and a half months to exclude the possibility of superadded syphilis.

Male cases are under observation for at least a month after the cessation of all treatment, and during this time, in addition to the absence of discharge and the maintenance of clear urine, repeated smears of the urethral, prostatic, and seminal vesicular secretions must be free from pathogenic organisms and relatively free from pus cells. These smears must also remain pus-free and organism-free fortyeight hours after a provocative intramuscular injection of 300 to 500 million organisms in a polyvalent gonococcal vaccine. The gonococcal complement-fixation test of the blood must be observed to remain negative or become negative during the period of observation. Instrumental investigation, including urethroscopy, must show a return of the urethral lining to normal.

Female cases are observed for three months after cessation of treatment, and during this time, in addition to the absence of discharge, repeated smears of the urethral, Bartholinian, and cervical canal secretions must be free from pathogenic organisms, especially immediately after the menstrual periods, and also forty-eight hours after the injection of 300 millions of the provocative polyvalent gonococcal vaccine. The gonococcal complementfixation test of the blood must remain negative or must become negative, and careful bimanual examination must exclude any residua in the uterus or tubes.

Cases claimed as "apparent cures" include some who have not been observed for the minimum periods stated above. In all cases smears were examined very frequently, often daily at first, and the presence of any discharge or other sign of inflammation and the condition of the urine were noted.

\section{Male Adult Cases}

ACUTE ANTERIOR URETHRITIS (49 CASES)

The average daily dose was 3 grammes maintained for an average of about five days, and this was followed in some cases by a reduced dose for a maximum of seven to nine days.

There was apparent cure in forty-three cases, and apparent or possible failure in six cases. In the apparent cures, clinical signs disappeared in under four days (average), and gonococci were absent in smears after two days (average). In the apparent failures, in three cases gonococci were present in smears after the course of drug treatment; of these one received 16 grammes in four days; in the second case treatment was very irregular, 12 grammes being taken in eight days as follows-3, 0,0 , $3,3,0,0,3$. The third case relapsed, and gonococci reappeared in the smears one week after the first course of 15 grammes, but the discharge and the gonococci disappeared quickly on beginning a second course. Two other cases had a return of discharge after 16 grammes in five days, but no gonococci were found in smears; in another case a slight mucoid discharge showing no gonococci in smears persisted after six days of drug treatment.

SUBACUTE GONORRHOEA (ANTERIOR URETHRITIS): 5 CASES

In all these five cases clinical cure was attained in an average of just over four days. A peri-urethral abscess and a sinus discharging gonococcal pus cleared up within a week.

ACCTE, SLBACUTE, AND CHRONIC ANTERIOR AND POSTERIOR URETHRITIS (25 CASES)

In twenty-one of the cases there were complications such as prostatitis, seminal vesiculitis, epididymitis, arthritis, and iritis. In all these cases the urethral discharge cleared up in just over five days and all the complications improved rapidly, including the cases of prostatitis (one with sciatica), arthritis, and even the iritis.

PREVIOUS TREATMENT WITH DRUGS OF THE SULPHANILAMIDE CLASS

Three of the male cases had relapsed after treatment with uleron, one having received two courses each of 20 grammes; the other two had received 16 grammes and $13 \frac{1}{2}$ grammes respectively. In the last of these three cases irrigation had also failed, and was stopped when $M$ \& $B$ 693 was started. Two of the three cases which had previously received uleron showed toxic symptoms with M \& B 693.

Fifteen cases had been treated with sulphanilamide: of these cases thirteen which showed gonococci in smears were clinically cured in five days; one case relapsed after M \& B 693, and gonococci reappeared in smears. Two cases developed jaundice after sulphanilamide therapy followed by M \& B 693 -one twenty-five days, the other twenty-seven days, after receiving the " 693 ."

Two cases had no toxic manifestations with M \& B 693 after having had such symptoms as headache, dizziness, and skin eruption while on sulphanilamide, but the dosage of the latter drug was twice that of the "693."

\section{Female Adult Cases}

NORMAL DOSAGE (19 CASES)

In seventeen cases the average dose was 2 grammes daily for just over six days, and the other two each received 3 grammes daily for five days. No local treatment was applied other than sitz baths and powdering of the vulva.

Therapeutic Effect.-In sixteen cases gonococci were absent from smears in under three days. Clinical signs such as discharges persisted on the average up to fourteen days. There was only one case of relapse with reappearance of gonococci in the smears, and two cases defaulted. 


\section{INIENSIVE DOSAGE}

After the initial dose of $\frac{1}{2}$ gramme four-hourly, four cases received four-hourly doses of 2 grammes, 2 grammes, 1 gramme continued, and finally tapering off to $\frac{1}{2}$ gramme in a manner similar to the procedure recommended for cases of pneumonia, the total duration of treatment averaging eight and a half days. In these cases the gonococcus was not found in smears after an average of two days. No relapses were noted during the period of observation. All the cases on intensive dosage developed severe nausea, violent vomiting, and prostration on the first day, although they had tolerated the initial dose of half a gramme.

\section{Toxic Effects on Normal Dosage}

Toxic effects were observed in twenty of the seventynine male adult cases and in seven of the nineteen adult females. The symptoms, although slight in the majority, were severe enough to necessitate withdrawal of M \& B 693 in eight cases (three men and five women), but not before the drug had been given for an average of six days, a sufficient period for it to exert the usual favourable influence on the gonorrhoea. The skin rashes were blotchy, erythematous or papular, and morbilliform in type, affecting the hands, arms (forearms especially), legs (thighs especially), abdomen, and back. The face was not in-

TABLE I.-Showing the Nature and Incidence of Toxic Symptoms in Patients on Normal Dosage

\begin{tabular}{|c|c|c|c|c|c|c|c|c|c|}
\hline & & & & & & & & Inci & nce in \\
\hline & & & & & & & & Men & Women \\
\hline Headache .. & . & . & . & . & .. & .. & $\ldots$ & 8 & 2 \\
\hline Nausea $\quad$. & .. & .. & $\cdots$ & .. & $\cdots$ & .. & .. & 6 & 2. \\
\hline Dizziness .. & .. & . & $\cdots$ & $\therefore$ & $\cdots$ & $\cdots$ & . & 3 & - \\
\hline Skin eruption & .. & . & .. & .. & .. & .. & .. & 2 & 4 \\
\hline Lassitude .. & .. & . & .. & $\cdots$ & $\cdots$ & $\cdots$ & $\cdots$ & 2 & 2 \\
\hline Cyanosis .. & $\cdots$ & $\cdots$ & $\cdots$ & $\cdots$ & $\cdots$ & $\cdots$ & $\cdots$ & 2 & - \\
\hline Vomiting ... & .. & $\cdots$ & . & .. & -. & -. & -. & 1 & 1 \\
\hline Breathlessness & .. & $\cdots$ & .. & $\cdots$ & $\cdots$ & $\cdot$ & .. & 1 & - \\
\hline Diarrhoea & .. & $\cdots$ & -. & $\cdots$ & $\cdots$ & ・. & .. & 1 & - \\
\hline Emptiness and & nunger & . & $\cdots$ & $\cdots$ & $\cdots$ & $\cdots$ & $\cdots$ & 1 & - \\
\hline
\end{tabular}

volved in the most severe eruption seen. There were no cases of photosensitivity in which the eruption is confined to the exposed parts-face, neck, hands, and forearmsalthough this type of rash has been found in cases treated with sulphanilamide.

The nature and incidence of the toxic symptoms in patients on normal dosage are shown in Table I, some patients exhibiting more than one symptom. All the toxic effects subsided quickly on withdrawal of the drug. One woman felt sick with six tablets ( 3 grammes) daily, but tolerated four tablets a day. One woman had sickness and lassitude with more than three tablets daily for four days, but nevertheless showed a very good clinical response.

\section{Children with Gonococcal Vulvovaginitis (4 Cases)}

These cases received no adjuvant treatment other than sitz baths and powdering of the vulva, with one exception in which menformon was given by injection and orally for two days before the drug treatment was started. As they are of special interest a synopsis of their clinical history is given in Table II.

\section{Management of a Case}

There is no necessity to wait for immunity to develop; $M$ and B 693 should be used as soon as the diagnosis is made. The technique suggested by our experience is as follows :

Men should receive six $\frac{1}{2}$-gramme tablets a day for five days-two tablets thrice daily after food, or, alternatively, two after breakfast, one after lunch, one after tea, and two after dinner or supper. After five days the dose should be reduced to three tablets, or at most four tablets, a day, continued for another five to nine days. The majority are cured by the first five days' treatment.

Women should receive four $\frac{1}{2}$-gramme tablets daily for five days-one tablet after each of the principal meals, or as follows: one tablet after breakfast, half a tablet at noon; half a tablet at 3 p.m., half a tablet at 6 p.m., and one and a half tablets at bedtime. After the first five days the dose should be reduced to three tablets a day, and be maintained at this levei for another five days.

Girls with vulvovaginitis should receive, for the first five days, half a tablet from four to six times daily, according to age, and thereafter, for the next five days, half a tablet thrice daily.

TABLE II.-Clinical History of 4 Cases of Gonococcal Vulvovaginitis in Children

\begin{tabular}{|c|c|c|c|c|c|c|}
\hline $\begin{array}{l}\text { Case No. } \\
\text { and Age }\end{array}$ & Nature of Infection & $\begin{array}{l}\text { Number of } \\
\text { Days' Treat- } \\
\text { ment till } \\
\text { Disappear- } \\
\text { ance of } \\
\text { Clinical Signs }\end{array}$ & Dosage & Relapses & Toxic Effects & Remarks \\
\hline $\begin{array}{l}2747 \\
\text { Aged } 5\end{array}$ & $\begin{array}{l}\text { Recent acute vulvo- } \\
\text { vaginitis - gonococci } \\
\text { present in smears } \\
\text { from urethra and } \\
\text { vagina }\end{array}$ & 2 & $\begin{array}{l}0.25 \mathrm{gm} \text {. thrice daily for } 5 \\
\text { days }\end{array}$ & $\begin{array}{l}\text { None. Observed for } 78 \text { days } \\
\text { after first negative smears }\end{array}$ & None & $\begin{array}{l}\text { One injection menformon } \\
(25,000 \text { units }) \text { and menfor- } \\
\text { mon tablets for } 2 \text { days before } \\
\mathbf{M} \& \text { B } 693 \text { started, but } \\
\text { smears still contained gono- } \\
\text { cocci }\end{array}$ \\
\hline $\begin{array}{l}2779 \\
\text { Aged s }\end{array}$ & $\begin{array}{l}\text { Recent acute vulvo- } \\
\text { vaginitis ; gonococci } \\
\text { present in smears } \\
\text { from urethra and } \\
\text { vagina }\end{array}$ & 3 & $\begin{array}{l}1 \mathrm{gm} \text {. daily for } 5 \text { days ( } \frac{1}{2} \text { tab- } \\
\text { let every } 6 \text { hours) }\end{array}$ & $\begin{array}{l}\text { None. Observed for } 30 \text { days } \\
\text { after first negative smears }\end{array}$ & $\begin{array}{l}\text { Neutrophil poly- } \\
\text { morphs reduced from } \\
64 \% \text { to } 41 \%\end{array}$ & $\begin{array}{l}\text { At start of treatment } \\
\text { white blood corpuscles } \\
15,000 \text { (neutrophil poly; } \\
\text { morphs } 64 \% \text { ). After } 5 \text { days' } \\
\text { treatment white blood cor- } \\
\text { pliscles } 11,000 \text { (neutrophil } \\
\text { polymorphs } 41 \% \text { ) }\end{array}$ \\
\hline $\begin{array}{l}2780 \\
\text { Aged } 9\end{array}$ & $\begin{array}{l}\text { Recent acute vulvo- } \\
\text { vaginitis; gonococci } \\
\text { present in smears } \\
\text { from vagina and } \\
\text { urethra }\end{array}$ & 4 & $\begin{array}{l}1 \text { st Course : } 1 \frac{1}{\mathrm{~g}} \mathrm{gm} \text {. daily } \\
\text { for } 5 \text { days }\left(\frac{1}{2} \text { tablet every } 4\right. \\
\text { hours) } \\
\text { 2nd Course: } 17 \mathrm{gm} \text {. daily } \\
\text { for } 5 \text { days }\end{array}$ & $\begin{array}{l}\text { On 10th day after starting } \\
\text { treatment gonococci in } \\
\text { smears, but no clinical signs. } \\
\text { No relapse in } 15 \text { days after } \\
\text { second course. }\end{array}$ & $\begin{array}{l}\text { Nausea, vomiting. } \\
\text { Dose reduced to } 1 \mathrm{t} \\
\text { gm. daily }\end{array}$ & $\begin{array}{l}\text { After } 5 \text { days white blood } \\
\text { corpuscles } 6,800 \text { (neutrophil } \\
\text { polymorphs } 55 \% \text { ) }\end{array}$ \\
\hline $\begin{array}{l}\text { A4602 } \\
\text { Aged } 10\end{array}$ & $\begin{array}{l}\text { Recent acute and } \\
\text { severe vulvovaginitis; } \\
\text { gonococci present in } \\
\text { smears }\end{array}$ & 5 & 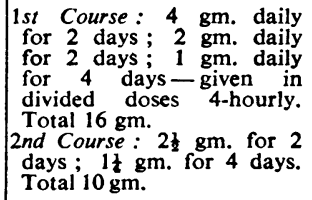 & $\begin{array}{l}\text { On } 15 \text { th day after starting } \\
\text { treatment gonococci re- } \\
\text { appeared in smears. No } \\
\text { relapse } 6 \text { weeks after com- } \\
\text { pletion of the second course }\end{array}$ & $\begin{array}{l}\text { Nausea on the 2nd } \\
\text { day, but was able to } \\
\text { continue on the re- } \\
\text { duced dose }\end{array}$ & $\begin{array}{l}\text { Gonococci absent after 4th } \\
\text { day of first course and after } \\
\text { 1st day of second course }\end{array}$ \\
\hline
\end{tabular}


The tablets are best taken powdered and in half a tumblerful or more of water. During the drug treatment patients should be warned not to take sulphur-containing foods such as eggs and onions, and, if laxatives are necessary, to use only liquid paraffin or extract of cascara, avoiding especially Epsom salts or liquorice powder.

\section{Conclusions}

1. M \& B 693 can effect clinical cure within a week in a large majority of cases of gonococcal infection, whether of short or long duration and whether occurring in men or in women.

2. Complications originally present, such as epididymitis, arthritis, or iritis, improve rapidly.

3 . In the cases quoted there was complete absence of complications or spread of the disease after the start of the drug therapy.

4. No irrigation or other adjuvant treatments are necessary.

5. Toxic effects may occur in less than one-third of the cases, but where normal dosage is employed these are usually mild, requiring only a reduction of the dose.

6. Toxic symptoms are quickly recovered from, and no lasting ill effects have been encountered

7. Vulvovaginitis also responds well to M \& B 693.

8. Our experience has led us to conclude that $M$ \& B 693 is the most potent anti-gonococcal agent available at present.

\section{Summary}

A report is given of 102 cases of gonococcal infection treated with M \& B 693

The standard of cure aimed at is discussed, along with the general results of treatment.

The clinical history of four cases of vulvovaginitis in children is detailed.

Points on the management of a case are given.

We are indebted to Messrs. May and Baker for supplies of the drug and to Dr. Robert Forgan for advice and literature.

\section{INTERNATIONAL HOSPITAL ASSOCIATION}

Toronto, September, 1939

At a recent meeting of the United Kingdom Council of the International Hospital Association, presided over by Mr. W. McAdam Eccles, M.S., F.R.C.S., chairman, there was received a preliminary but very detailed programme of the sixth Biennial Congress of the I.H.A. to be held at Toronto in September, 1939.

The task of the production of this programme has been in the capable hands of Dr. Malcolm T. MacEachern, President of the I.H.A., and Associate Director of the American College of Surgeons, with the assistance of Dr. Harvey Agnew, Secretary of the Canadian Hospital Council and Presidentelect of the American Hospital Association. Associated with them have been Dr. William S. Coldwell, chairman of the Congress Committee and assistant medical director of the Canadian Red Cross, and the secretary, Mr. Carl T. Flath. By all concerned with the I.H.A. in Great Britain, in the British Empire. and on the Continent, and above all in Canada and the United States, it is believed that this coming congress will be unique in the annals of international hospital affairs, and will stand to show the co-operation of the whole civilized world in the prevention of and the dealing with disease in the modern manner. Forty study committees will be reporting upon their individual work during the preceding two years, and papers of great interest will be read by many experts during the week of the Congress, September 19 to 23 .

All particulars concerning the subjects to be discussed and of the travel arrangements to Toronto and back can be obtained from the joint hon. secretaries of the I.H.A., 17, Bloomsbury Square, London, W.C.1.

\section{Clinical Memoranda}

\section{Primary Intussusception of the Appendix}

Primary intussusception or inversion of the appendix, without complication, is probably a sufficiently rare curiosity to merit report of a case which came under my care while acting surgeon at Offaly (King's) County Hospital, Tullamore.

\section{CASE REPORT}

The patient, a young man aged 20 , was admitted to hospital after a severe attack of colicky abdominal pains accompanied by vomiting; the symptoms had been present in lesser degree at intervals over the two preceding days. On admission his temperature was $99^{\circ} \mathrm{F}$. and the pulse rate 80 . Slight tenderness was elicited on deep palpation of the right iliac fossa. Rigidity was not in evidence, nor was any mass felt.

On the following morning the abdomen was opened through a McBurney incision, but the caecum was not delivered with the ease anticipated, nor was the appendix felt. On enlarging the incision and delivering the caecum the three taeniae coli were seen to converge on a tiny dimple into which ran a taut band-the meso-appendix. The appendix was felt as a

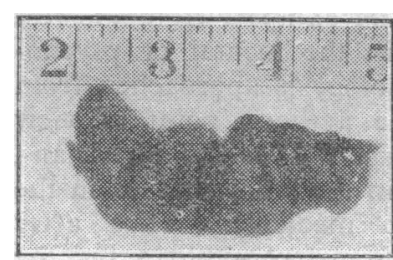

FIG. 1.

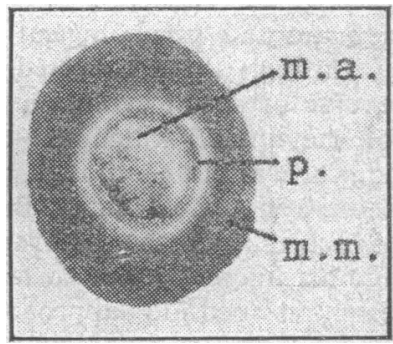

FIG. 2
FIG. 1.-The specimen (scale, inches).

FIG. 2.-Cross-section of the specimen (actual size). m.a. $=$ meso-appendix $;$ p. = peritoneum $; \mathrm{m} . \mathrm{m} .=$ mucous membrane.

sausage-shaped mass fixed at the caput caeci, lying within the caecal cavity. Its size indicated engorgement, and an effort to evert it was quite futile. The meso-appendix was ligated and severed and an intestinal clamp lightly placed across the caput caeci, within which lay the appendix. After packing off, the caecal wall was opened by an incision which ended at the site of inversion, the appendix was delivered, and the incision carried round its base. With the usual toilet, closure of the caecum in two layers, and adequate drainage, the operation was concluded in the ordinary way.

Convalescence was uneventful, and the patient was discharged from hospital after eighteen days by the surgeon, Dr. T. Meagher, who had then resumed duties.

I am indebted to Dr. W. R. O'Farrell, pathologist to the Mater Misericordiae Hospital, for the following report on the specimen: "The specimen is a complete inversion of the vermiform appendix. Section shows a central mass of fatty tissue containing large vessels - the meso-appendix; external to this is the muscular coat and the mucous membrane, which shows in places the subepithelial collections of lymphocytes. The whole mass is congested and inflamed. The inversion is complete, and includes the tip of the appendix."

The usual explanation of the condition-an attempt to extrude a concretion or an enlarged lymphatic follicleprobably holds in this case.

Dublin.

John CORCORAN, M.Ch., Surgical Assistant, Mater Miscricordiae Hospita. 